\title{
Wpływ muzyki na funkcjonowanie poznawcze człowieka1
}

\begin{abstract}
The results of studies are connected with influence of music in the cognitive functions are different. In this article, the review of literature and the results of the own study were presented. The own study $(\mathrm{N}=132)$ is connected with influence of music in the results of concentration task. Difficulty of tasks and knowledge of pieces of music were manipulated. The analysis presents that the task was performance better with piece of music than without. The results suggest that during performance the simple cognitive task, extra stimulus does not reduce the result of this task.
\end{abstract}

Keywords: psychology of music, concentration, education

\section{Wprowadzenie}

Odbiór utworu muzycznego warunkowany jest wieloma czynnikami, zależnymi od predyspozycji człowieka, związanymi ze zdolnościami poznawczymi, wykształceniem muzycznym czy cechami temperamentalnymi, a także cechami samego utworu. Badania nie przynoszą jednoznacznych rezultatów dotyczących tego, jak muzyka wpływa na nasze funkcjonowanie poznawcze. Potwierdzają to wyniki badań, które $\mathrm{z}$ jednej strony sugerują, że obecność muzyki podwyższa wyniki zadań poznawczych, $\mathrm{z}$ drugiej $\mathrm{w}$ niektórych grupach powoduje obniżenie rezultatów tych samych zadań [np. Lummis i in., 2017; Furnham i Allass, 1999]. Zarówno dla samego słuchania utworu muzycznego, jak i wykonywania zadań poznawczych znaczącą rolę odgrywa uwaga, wykształcenie muzyczne, temperament, cechy samego utworu oraz warunki, w jakich odbywa się przetwarzanie materiału i słuchanie muzyki. Niezależnie od wyboru utworu czy zadania, pionierskie badania związane z możliwością przetwarzania kilku informacji jednocześnie wskazują, że niemożliwe jest wykonanie dwóch zadań w tym samym czasie, które dotyczą tego samego kanału przetwarzania informacji. Przykładem są badania Cherrego [1953; za: Sloboda, 2002], które dowodzą, że jeśli zadaniem osoby badanej jest jednoczesny odbiór dwóch przekazów słownych, w rezultacie badany może przytoczyć tylko jeden z nich. Kolejne badanie kwestionuje

1 Artykuł powstał na podstawie pracy magisterskiej napisanej pod kierunkiem Małgorzaty Przepióry-Kapusty. Podziękowanie za wsparcie merytoryczne i edytorskie Aleksandrze Gruszce-Gosiewskiej. 
tak zwaną teorię „filtra”. Z kolei Allport wraz ze współpracownikami [1972; za: Sloboda, 2002] pokazał, że możliwe jest wykonywanie dwóch czynności jednocześnie, jeśli nie wykorzystują tych samych mechanizmów poznawczych, co przyczynia się na przykład do zdolności słuchania muzyki i jednoczesnego czytania. Odbiór muzyki warunkowany jest także wykształceniem muzycznym. Berlyne [1971; za: Pałosz, 2009] udowodnił, że upodobanie do danego zestawu bodźców muzycznych zależy od spostrzeganej trudności utworu oraz zdolności technicznych, które dotyczą umiejętności muzycznych. Davies [1978; za: Manturzewska, 1990] wskazał na zależność związaną ze złożonością utworu. Według niego pobudzenie i zaciekawienie toruje drogę preferencjom. Zainteresowanie jest związane $\mathrm{z}$ wyższym stopniem złożoności utworu, natomiast uczucie przyjemności - z niższym jej poziomem. Brak umiejętności rozumienia znaczenia muzyki może przyczyniać się do powstawania błędów w rozumieniu utworu. Gordon [1998; za: Zwolińska, 2014] zwrócił uwagę na fakt, że podczas słuchania muzyki ulegamy jej wpływowi, co decyduje o formułowaniu się poglądów i podejmowaniu decyzji. Związane jest to z ograniczonymi zasobami poznawczymi i brakiem motywacji do angażowania się w działania muzyczne. Warto podkreślić istnienie różnic w kontekście zapamiętywania między muzykami i osobami, które nie są zawodowymi muzykami. Uczenie się przy muzyce może inaczej wpływać na wyniki przypominania zapamiętanych treści przez muzyków i osoby, które nie mają umiejętności muzycznych. Różnice w odtwarzaniu zapamiętanych słów piosenek przez muzyków i osoby niebędące zawodowymi muzykami pokazują wyniki badania Lummis, McCabe, Sickles, Byler, Hochberg, Eckart i Kahler [2017]. Rezultaty wskazują na to, że muzyka może ułatwiać zapamiętywanie i muzycy mogą mieć przewagę w przywoływaniu śpiewanych i czytanych tekstów piosenek. Z kolei uczenie oparte na muzyce może wpływać na poczucie presji czasu, ale także doświadczanie wyższego sukcesu zadania. Muzycy w porównaniu z osobami niemającymi umiejętności muzycznych mogą odczuwać mniejszą aktywność umysłową podczas uczenia się przy utworach dźwiękowych. Inne zależności związane $\mathrm{z}$ wpływem muzyki na wykonywanie zadań poznawczych ujawniają się, jeśli uwzględnione zostaną dodatkowe zmienne związane $\mathrm{z}$ temperamentem. Badanie Furnhama i Allass [1999] polegało na manipulacji złożonością bodźców dźwiękowych eksponowanych podczas wykonywania zadań sprawdzających zdolności poznawcze. Dokonano podziału grup eksperymentalnych na ekstrawertyków i introwertyków. Pokazano, że zwiększająca się złożoność muzyczna wpływa na wzrost wyników funkcji poznawczych u ekstrawertyków i spadek wyników u introwertyków. Natomiast badanie Wasieli [2004] dotyczące wpływu muzyki uspokajającej i pobudzającej na wyniki w teście koncentracji uwagi u ekstrawertyków i introwertyków nie pokazuje znaczących statystycznie różnic między tymi grupami. Muzyka pobudzająca zwiększała wyniki testu u ekstrawertyków, natomiast niespodziewanie u introwertyków poziom wyników uzyskanych w testach przy muzyce pobudzającej i uspokajającej był prawie identyczny. Wyniki zadań poznawczych podczas jednoczesnego słuchania muzyki zależą także od cech fizycznych samego utworu oraz sposobu, w jaki odbierają go słuchacze. Do tej pory nie wyodrębniono uniwersalnego modelu, który pokazuje, jaki gatunek muzyczny działa najskuteczniej na dany typ zadań poznawczych, i wydaje się to rzeczą nierealną, biorąc pod uwagę wyniki wcześniejszych badań, dlatego też opieramy się na ogólnych wynikach, które są próbą 
pokazania tego, jak cechy utworu wpływają na osoby badane i wyniki wykonywanych przez nie zadań poznawczych. Już w latach trzydziestych XX wieku Fendrick [1937; za: Wierszyłowski, 1981] stwierdził, że muzyka może przeszkadzać niektórym osobom w uczeniu się trudnego materiału. Z kolei badania Freeberbe’a i Fleischera [1952, 1955; za: Wierszyłowski, 1981] dowiodły, że muzyka jazzowa działa uspokajająco na uczących się, zwłaszcza gdy praca ma charakter rywalizacyjny i jest ukierunkowana na szybkie wykonywanie zadań. Może to sugerować, że na efekty pracy podczas muzyki wpływają cechy danego utworu oraz zadania. W literaturze można znaleźć wyniki badań, które wskazują na rolę podobania się zastosowanego utworu muzycznego w kontekście wykonywania zadania Stroopa. W badaniu Braya, Oliver, Grahama i Ginis [2013] wykorzystano utwory muzyczne zgodne z preferencjami badanych oraz zadanie Stroopa do mierzenia samokontroli. Wbrew przewidywaniom wyniki wskazują na to, że obecność muzyki nie osłabia samokontroli osób badanych. Co więcej, rezultaty w grupie wykonującej zadanie podczas słuchania muzyki były wyższe niż w grupie wykonującej zadanie Stroopa w ciszy. Autorzy badania, odwołując się do teorii Fredrickson [1998; za: Bray, Oliver, Graham i Ginis, 2013] sugerują, że dzięki pozytywnym emocjom, które wywołały piosenki, zgodne z preferencją badanych, poszerzył się ich zakres uwagi, co zwiększyło zasoby fizyczne i psychologiczne w tej sytuacji badawczej. Obok kwestii doboru muzyki związanej z preferencjami osób badanych istotne jest też tempo utworu. Badanie Baldwina i Lewis [2017] świadczy na korzyść tezy, że prezentowany utwór warunkuje szybkość działania. Szybkie grupy utworów wpływały na szybszą ich ocenę przez badanych w porównaniu z muzyką wolną. W literaturze można znaleźć również wyniki badań, które przedstawiają niejednoznaczny wpływ muzyki na rezultaty zadań. Na przykład badanie Perhama i Currie [2014] udowadnia, że wyniki zadania polegającego na czytaniu ze zrozumieniem zależą od rodzaju zastosowanego utworu. Zadaniem osób badanych było wykonanie zadania sprawdzającego czytanie ze zrozumieniem przeczytanego fragmentu prozy. Wykorzystano nielubianą muzykę liryczną, lubianą muzykę liryczną, muzykę nieliryczną oraz muzykę grającą cicho. Najlepsze rezultaty uzyskała grupa wykonująca zadanie podczas słuchania cichej lub nielirycznej muzyki.

Z perspektywy wykonywania zadań poznawczych podczas słuchania muzyki istotne są też warunki, w jakich odbywa się przetwarzanie materiału i odbieranie utworu. Przegląd literatury wskazuje na różnice w wynikach zadań spowodowanych wyborem ćwiczeń, które wymagały wykorzystania różnych zdolności związanych z procesami poznawczymi. Inną sytuacją jest wykonywanie zadania po wcześniejszym uczeniu się tych treści podczas słuchania muzyki, inną sytuacją jest wykonywanie zadania bez konieczności przywoływania treści z pamięci. Tłumaczyć to może zgodność pomiędzy sytuacją uczenia się a odtwarzania informacji, na którą zwracał uwagę Anderson [1983]. Związane jest to $\mathrm{z}$ czasem wymaganym do wydobycia $\mathrm{z}$ pamięci danej informacji, co zależy od poziomu aktywacji danej wiadomości. Gdy aktywacja jest rozpraszana w sytuacji zastosowania dodatkowych bodźców, wówczas zwiększa się czas wyszukiwania danych. Czas ten może zostać zredukowany w wyniku zgodności sytuacji. Na ten efekt wskazywało na przykład przeprowadzone w ramach pracy magisterskiej badanie Białeckiego [2006, za: Czerniawska, 2012] z zastosowaniem muzyki instrumentalnej Mozarta, utworu zespołu Abba oraz chińskiej muzyki ludowej 
podczas wykonywania zadań sprawdzających pamięć. Wynikało z niego, że muzyka odległa kulturowo zakłóca procesy pamięciowe, ponieważ silniej angażuje uwagę osób badanych w porównaniu z muzyką popularną. Tym samym wynik zadania zależał od prezentowanego utworu muzycznego. Interesujący jest przykład badania [Domański, 2005, za: Czerniawska, 2012], które pokazuje, że wynik wykonywanego zadania jest zależny od cech prezentowanego utworu. Badanie eksperymentalne polegało na zapamiętaniu słów w języku angielskim przez osoby badane. Po zapamiętaniu listy słów, w zależności od grupy, osoby badane słuchały utworu muzycznego (utwór muzyczny: $\mathrm{z}$ liryką w języku angielskim, $\mathrm{z}$ liryką $\mathrm{w}$ języku polskim oraz w wersji instrumentalnej), grupa kontrolna nie słuchała muzyki. Następnie badani odtwarzali zapamiętane słowa. Wyniki pokazują, że muzyka z liryką znacząco pogorszyła rezultaty odtwarzanych słów w porównaniu z muzyką instrumentalną oraz brakiem muzyki. Najgorsze wyniki zadania uzyskała grupa słuchająca utworu z liryką w języku angielskim. Rezultaty badania doprowadziły do wyodrębnienia pewnej prawidłowości, która sugeruje, że im większe jest podobieństwo utworu do wykonywanego zadania, tym gorsze są jego wyniki. Z kolei badanie polegające na uczeniu się materiału werbalnego podczas stymulacji muzycznej wykazało, że tempo utworu muzycznego nie miało wpływu na naukę tego typu materiału [Jäncke, Sandmann, 2010]. Istnieją również wyniki pokazujące pozytywny wpływ muzyki na zapamiętywanie materiału wizualnego. Pojawiające się obrazy ukazywane były badanym po wysłuchaniu utworów zgodnych z ich preferencjami oraz takich, do których mieli obojętny stosunek. Zgodnie z przewidywaniami najwięcej szczegółów odtworzono, gdy wcześniej badani słuchali muzyki wywołującej stan pobudzenia [Carr i Rickard, 2010]. W świetle powyższych niejasności, celem prezentowanego badania była odpowiedź na pytanie, jak dany rodzaj muzyki wpływa na wynik zadania na koncentrację uwagi. Postawione pytanie badawcze jest ważne szczególnie $\mathrm{w}$ dzisiejszych czasach, ponieważ ludzie - $\mathrm{w}$ tym również uczniowie - coraz częściej wykonują kilka czynności jednocześnie. Taki styl pracy stał się na tyle powszechny, że przyjęto nazwę określającą wielozadaniowość (ang. multitasking). Ze względu na częstość występowania tego zjawiska, głównie wśród nastolatków, mówi się o kulturze multitaskingu, czego długotrwałą konsekwencją mogą być między innymi problemy z uczeniem się i pamięcią długotrwałą [np. Bühner i in., 2006; Ophir i in., 2009, za: Ralph i in., 2014].

Na podstawie powyższego przeglądu badań postawiono następujące hipotezy:

1. Zarówno muzyka znana, jak i nieznana podnosi wynik zadania na koncentrację uwagi w porównaniu z sytuacją, gdy zadanie wykonywane jest bez muzyki.

2. Muzyka znana osobie badanej obniża wynik łatwego zadania na koncentrację uwagi w porównaniu z sytuacją, gdy zadanie wykonywane jest przy muzyce nieznanej.

3. Muzyka znana obniża wynik łatwego zadania na koncentrację uwagi w porównaniu z zadaniem trudnym.

4. Muzyka nieznana podnosi wynik łatwego zadania na koncentrację uwagi $\mathrm{w}$ porównaniu $\mathrm{z}$ zadaniem trudnym.

W literaturze nie znaleziono przykładów badań, które pokazują rolę ukończenia szkoły muzycznej, zwyczajowego uczenia się przy muzyce, podobania się słuchanego utworu czy zgodności słuchanego utworu z preferencjami muzycznymi w kontekś- 
cie wykonywania zadania poznawczego podczas jednoczesnego słuchania muzyki. W związku z tym postawiono kolejne hipotezy o charakterze eksploracyjnym:

5. Osoby deklarujące słuchanie muzyki podczas nauki osiągają wyższe wyniki w zadaniu poznawczym niż badani, którzy nie uczą się przy muzyce.

6. Osoby będące absolwentami szkoły muzycznej osiągają wyższe wyniki zadania podczas słuchania muzyki niż osoby, które nie ukończyły szkoły muzycznej.

7. Osoby wykonujące zadanie przy muzyce zgodnej z ich upodobaniami osiągają wyższe wyniki niż osoby wykonujące zadanie przy muzyce niezgodnej $\mathrm{z}$ ich upodobaniami.

\section{Metoda}

\section{Osoby badane}

Pierwsze badanie pilotażowe było poświęcone uzyskaniu ocen znajomości utworów muzycznych i przeprowadzono je wśród czterech absolwentów Państwowej Szkoły Muzycznej oraz sześciu studentów psychologii. Celem drugiego badania pilotażowego był wybór zadań na koncentrację uwagi i określenie stopnia trudności wykonanych ćwiczeń. Dziesięć wybranych ćwiczeń z książki z zadaniami na koncentrację uwagi dla uczniów gimnazjum i szkół ponadgimnazjalnych [Jurek, 2012] wykonało dwudziestu uczniów. Badanie właściwe obejmowało udział 132 uczniów klas licealnych (17-18 lat) w podziale na cztery grupy eksperymentalne i grupę kontrolną.

\section{Procedura badawcza}

Po dokonaniu analizy badania pilotażowego wybrano dwa utwory (znany $v s$ nieznany) oraz dwa zadania - jedno zakwalifikowane z łatwym poziomem trudności, drugie jako trudne. Zadanie określone jako łatwe polegało na wyszukaniu w dwudziestu kolumnach wskazanej pary liter, zadanie trudne natomiast dotyczyło wyszukania z tabeli słów należących do rodziny wyrazów wskazanych wyrazów. Wybrane utwory były w wersji instrumentalnej. Utwór określony jako znany to ścieżka dźwiękowa do filmu Titanic - wersja instrumentalna utworu My Heart Will Go On, wykonywana przez Kennetha Gorelicka. Z kolei utwór nieznany osobom biorącym udział w badaniu pilotażowym to Danza de las espades.

\section{Przebieg badania}

Badanie odbywało się $\mathrm{w}$ naturalnych warunkach szkolnych, podział na grupy badanych i liczebność osób zależała od danej klasy. Manipulowano dwiema zmiennymi: rodzajem muzyki i trudnością zadania, $\mathrm{w}$ wyniku czego powstały cztery grupy eksperymentalne (muzyka znana - zadanie łatwe, muzyka znana - zadanie trudne, muzyka nieznana - zadanie łatwe, muzyka nieznana - zadanie trudne) oraz grupa kontrolna. 
Uczniowie byli informowani, że wezmą udział w badaniu, które dotyczy rozwiązywania zadania na koncentrację uwagi przy muzyce. Ograniczenie czasowe dla zadań trudnych wynosiło 10 minut, zaś dla zadań łatwych - 2 minuty. Po upływie wyznaczonego czasu badani otrzymywali ankietę, aby odpowiedzieć na pytania.

Grupa kontrolna rozwiązywanie zadania rozpoczynała od ćwiczenia trudnego. Po upływie wyznaczonego czasu osoby badane otrzymywały kolejne ćwiczenie - zadanie łatwe. Po rozwiązaniu zadania wypełniali ankietę.

Zadanie określone jako łatwe polegało na znalezieniu w kolumnach powtarzających się par liter, zadanie trudne natomiast wymagało wpisania podanych wyrazów do danych słów zgodnie z tworzeniem rodziny wyrazów. Należy zaznaczyć, że wybrane zadania nie wymagały wiedzy od osób badanych, a ich prawidłowe wykonanie wymagało intensywnej koncentracji uwagi.

\section{Analiza wyników}

Ze względu na odbiegający od normalnego rozkład otrzymanych wyników wszystkie analizy statystyczne weryfikujące postawione hipotezy przeprowadzono nieparametrycznym testem U Manna-Whitneya. Ostateczne wyniki testów istotności różnic w odniesieniu do postawionych hipotez przedstawia tabela 1.

\section{Rodzaj muzyki i stopień trudności zadania}

Hipoteza sugerująca, że zarówno muzyka znana, jak i nieznana podnoszą wynik zadania na koncentrację uwagi, została potwierdzona $\left(\mathrm{M}_{\text {muzyka }}=0,92\right.$ i SD $_{\text {muzyka }}=0,12$ $v s \mathrm{M}_{\text {brak muzyki }}=0,86$ i $\mathrm{SD}_{\text {brak muzyki }}=0,17 \mathrm{U}=4187$ dla $\left.\mathrm{p}<0,01\right)$.

Przeprowadzona analiza wyników nie pozwala przyjąć hipotezy drugiej. Osoby wykonujące zadanie łatwe przy muzyce znanej osiągają taki sam poziom koncentracji uwagi jak osoby rozwiązujące to samo zadanie przy muzyce nieznanej (M latwe $=0,98 \mathrm{i} \mathrm{SD}$ muz. znana_zad. tatwe $=0,04 v s \mathrm{M}_{\text {muz. nieznana_zad. latwe }}=0,89 \mathrm{i} \mathrm{SD}$ muz. nieznana_zad. tatwe $=0,19 \mathrm{U}=242$ dla $\mathrm{p}>0,05)$.

Analiza wyników dla hipotezy trzeciej wskazuje na różnice istotne statystycznie, ale niezgodnie z postawioną hipotezą. Osoby wykonujące zadanie łatwe przy słuchaniu muzyki znanej osiągają wyższe wyniki niż w zadaniu trudnym (M $=0,98$ i SD ${ }_{\text {muz. znana_tatwe }}=0,04 v s \mathrm{M}_{\text {muz. znana_zad. trudne }}=0,85 \mathrm{i} \mathrm{SD}$ muz. znana_zad. trudne $=0,12$ $\mathrm{U}=53$ dla $\mathrm{p}<0,01)$. Hipoteza przypuszczająca, że muzyka nieznana podnosi wynik zadania łatwego $\mathrm{w}$ porównaniu $\mathrm{z}$ zadaniem trudnym, może zostać przyjęta. Osoby wykonujące zadanie łatwe przy słuchaniu muzyki nieznanej osiągają wyższe wyniki niż osoby wykonujące zadanie trudne $\left(\mathrm{M}_{\text {muz. nieznana_zad. trudne }}=0,89 \mathrm{i} \mathrm{SD}\right.$ muz.nieznana_zad. trudne $=0,01$ vs $\left.\mathrm{M}_{\text {muz. nieznana_zad. fatwe }}=0,93 \mathrm{i} \mathrm{SD}_{\text {muz. nieznana_zad. tatwe }}=0,19 \mathrm{U}=160 \mathrm{dla} \mathrm{p}<0,01\right)$. 


\section{Predyspozycje muzyczne i wyniki zadań podczas słuchania muzyki}

Przeprowadzona analiza wyników pozwala przyjąć hipotezę mówiącą o tym, że osoby deklarujące słuchanie muzyki podczas nauki osiągają wyższe wyniki zadania niż badani, którzy nie uczą się przy muzyce $\left(\mathrm{M}_{\text {uczenie się przy muzyce }}=0,91 \mathrm{i} \mathrm{SD}_{\text {uczenie się przy muzyce }}=\right.$ 0,13 vs $\mathrm{M}_{\text {nieuczenie się przy muzyce }}=0,86 \mathrm{i} \mathrm{SD}_{\text {nieuczenie się przy muzyce }}=0,17 \mathrm{U}=4592$ dla $\left.\mathrm{p}<0,01\right)$.

Jeśli chodzi o hipotezę dotyczącą tego, że osoby będące absolwentami szkoły muzycznej osiągają wyższe wyniki zadania podczas słuchania muzyki niż osoby, które nie ukończyły szkoły muzycznej, nie ma różnic istotnych statystycznie $\left(\mathrm{M}_{\text {szkoła tak }}=\right.$ $0,92 \mathrm{i} \mathrm{SD}_{\text {szkoła tak }}=0,10$ vs $\mathrm{M}_{\text {szkoła nie }}=0,87 \mathrm{i} \mathrm{SD}_{\text {szkoła nie }}=0,17 \mathrm{U}=3519$ dla $\left.\mathrm{p}>0,05\right)$.

\section{Preferencje muzyczne i wyniki zadania}

Ostatnia hipoteza może zostać przyjęta. Wyższe wyniki zadania na koncentrację uwagi osiągają osoby rozwiązujące je podczas muzyki zgodnej z ich upodobaniami, w porównaniu z osobami wykonującymi to samo zadanie przy muzyce, która im się nie podobała $\left(\mathrm{M}_{\text {podobanie tak }}=0,93 \mathrm{iSD}\right.$ podobanie tak $=0,1$ vs $\mathrm{M}_{\text {podobanie nie }}=0,89 \mathrm{i} \mathrm{SD}$ podobanie nie $=0,16 \mathrm{U}=737$ dla $\mathrm{p}<0,01)$.

Tabela 1. Istotności statystyczne dla poszczególnych hipotez

\begin{tabular}{|c|c|c|}
\hline Hipoteza & Mediana i średnia & $\begin{array}{l}\text { Wynik testu U Manna- } \\
\text {-Whitneya i istotność } \\
\text { statystyczna }\end{array}$ \\
\hline $\begin{array}{l}\text { H1: Muzyka } v s \text { brak muzyki } \\
\text { a wynik zadania* }\end{array}$ & $\begin{array}{l}\mathrm{M}_{\mathrm{M}}=0,92 \mathrm{iSD}_{\mathrm{M}}=0,12 \text { vs } \mathrm{M}_{\mathrm{Bm}}=0,86 \\
\mathrm{i} \mathrm{SD}_{\mathrm{Bm}}=0,17\end{array}$ & $\mathrm{U}=4187, \mathrm{p}<0,01$ \\
\hline $\begin{array}{l}\text { H2: Muzyka znana } v s \\
\text { muzyka nieznana a zadanie } \\
\text { łatwe }\end{array}$ & $\begin{array}{l}\mathrm{M}_{\mathrm{Mz} \_z \mathrm{ft}}=0,98 \mathrm{i}_{\mathrm{SD}} \mathrm{Mz}_{\mathrm{Mz} z \mathrm{zt}}=0,04 \\
v s \mathrm{M}_{\mathrm{Mn} \_z \mathrm{ft}}=0,89 \mathrm{i} \mathrm{SD}_{\mathrm{Mn} \_z \mathrm{f}}=0,19\end{array}$ & $\mathrm{U}=242, \mathrm{p}>0,05$ \\
\hline $\begin{array}{l}\text { H3: Muzyka znana a wynik } \\
\text { zadania łatwego } v \text { s trudnego }\end{array}$ & $\begin{array}{l}\mathrm{M}_{\mathrm{Mz} Z z \mathrm{zt}}=0,98 \text { i SD } \\
v s \mathrm{M}_{\mathrm{Mz} \_ \text {zt }}=0,85 \mathrm{i} \mathrm{SD}_{\mathrm{Mz} \_ \text {zt }}=0,04 \\
=0,12\end{array}$ & $\mathrm{U}=53, \mathrm{p}<0,01$ \\
\hline $\begin{array}{l}\text { H4: Muzyka nieznana } \\
\text { a wynik zadania łatwego* }\end{array}$ & $\begin{array}{l}\mathrm{M}_{\mathrm{Mn} \_z \mathrm{t}_{1}}=0,89 \mathrm{iSD}_{\mathrm{Mn} \_\mathrm{zt}}=0,01 \\
v s \mathrm{M}_{\mathrm{Mn} \_z \mathrm{t}}=0,93 \mathrm{iSD}_{\mathrm{Mn} \_z \mathrm{t}}=0,19\end{array}$ & $\mathrm{U}=160, \mathrm{p}<0,01$ \\
\hline $\begin{array}{l}\text { H5: Słuchanie muzyki } \\
\text { a wynik zadania* }\end{array}$ & $\begin{array}{l}\mathrm{M}_{\text {tak }}=0,91 \mathrm{iSD}_{\text {tak }}=0,13 v s \mathrm{M}_{\text {nie }}=0,86 \\
\mathrm{i} \mathrm{SD}_{\text {nie }}=0,17\end{array}$ & $\mathrm{U}=4592, \mathrm{p}<0,01$ \\
\hline $\begin{array}{l}\text { H6: Ukończenie szkoły } \\
\text { muzycznej a wynik zadania }\end{array}$ & $\begin{array}{l}\mathrm{M}_{\mathrm{tak}}=0,92 \mathrm{i} \mathrm{SD}_{\text {tak }}=0,10 v s \mathrm{M}_{\text {nie }}=0,87 \\
\mathrm{i} \mathrm{SD}_{\text {nie }}=0,17\end{array}$ & $\mathrm{U}=3519, \mathrm{p}>0,05$ \\
\hline $\begin{array}{l}\text { H7: Podobanie się utworu } \\
\text { a wynik zadania* }\end{array}$ & $\begin{array}{l}\mathrm{M}_{\text {tak }}=0,93 \mathrm{i} \mathrm{SD}_{\text {tak }}=0,1 v s \mathrm{M}_{\text {nie }}=0,89 \\
\mathrm{i} \mathrm{SD}_{\text {nie }}=0,16\end{array}$ & $\mathrm{U}=737, \mathrm{p}<0,01$ \\
\hline
\end{tabular}

Opis oznaczeń:

Mz_zl - muzyka znana_zadanie łatwe, Mn_zl - muzyka nieznana_zadanie łatwe, $\mathbf{M}$ - muzyka, Bm brak muzyki, Mz_zt - muzyka znana_zadanie trudne, Mn_zt - muzyka nieznana_zadanie trudne, tak - uczenie się przy muzyce $v s$ ukończenie szkoły muzycznej $v s$ podobanie się utworu, nie - nieuczenie się przy muzyce $v s$ nieukończenie szkoły muzycznej $v s$ niepodobanie się utworu 


\section{Dyskusja wyników}

W prezentowanym badaniu podjęto próbę znalezienia odpowiedzi na pytanie, czy obecność muzyki wspomaga wykonywanie zadań na koncentrację uwagi. Przeprowadzone badanie ukazuje, że w przypadku wykonywania zadania łatwego rodzaj towarzyszącej wykonaniu muzyki nie wpływa istotnie statystycznie na jego efekt. Wyniki przeprowadzonego badania nie są jednak zgodne z postawioną hipotezą, a zatem prawem Yerkesa-Dodsona, według którego zadanie łatwe powinno być lepiej wykonywane przy muzyce nieznanej. Uzyskane wyniki może tłumaczyć fakt prostego zadania; być może gdyby zadanie było dobrane ze średnim stopniem trudności, wpłynęłoby to na odwrotne wyniki badania.

Uzyskane wyniki, zgodnie z badaniem Wasieli [2004], pokazują, że obecność muzyki wpływała na wyższe wykonanie zadań w porównaniu z sytuacją wykonywania ich w ciszy. Rezultaty badania własnego nie są zgodne z wynikami wcześniejszych eksperymentów [Białecki, 2006; Czerniawska, 2008, za: Czerniawska 2012] dotyczącymi wykorzystywania muzyki znanej, instrumentalnej i odległej kulturowo. W prezentowanym badaniu - w przeciwieństwie do danych wcześniejszych - najgorsze wyniki uzyskała grupa wykonująca zadanie w ciszy. Należy podkreślić, że prezentowane wyniki badań były związane z zadaniami dotyczącymi pamięci. Własne badanie obejmowało ćwiczenia sprawdzające koncentrację uwagi.

Zgodnie $\mathrm{z}$ prezentowanym w literaturze efektem kontrastu istotne jest, czy osoba badana zwyczajowo uczy się przy muzyce, czy nie. Choć zaplanowane zadanie w badaniu własnym nie wymagało odtwarzania treści, nauczenia się materiału, to być może, jeśli badany uczy się przy muzyce, tego samego spodziewa się przy wykonywaniu zadania, a tym samym brak muzyki utrudnia jego wykonanie. Ponadto ważnym elementem wpływającym na wyniki zadania w przeprowadzonym badaniu było podobanie się utworu.

Wyniki badania są użyteczne przede wszystkim w kontekście kształcenia młodzieży. Pokazują, że muzyka działa stymulująco i poprawia wyniki zadań, prawdopodobnie nie zawsze i nie u każdego ucznia w jednakowym stopniu. Przyzwyczajeni do multitaskingu uczniowie potrzebują dodatkowych bodźców przy wykonywaniu zadań, a cisza nie jest „lekiem na całe zło”.

Należy jednak wziąć pod uwagę brak uniwersalnego modelu wykonywania zadań podczas jednoczesnego słuchania muzyki, a zatem nie można jednoznacznie stwierdzić, iż brak bodźca muzycznego podczas wykonywania zadania na koncentrację uwagi obniża jego wynik. Ważnymi modyfikacjami w kolejnych badaniach może być wybór zmiennych zarówno w kwestii manipulacji utworami muzycznymi, jak i zadaniami, zarówno pod kątem stopnia trudności, jak i weryfikowania innych zdolności poznawczych. Interesujące może być też poprzedzające badanie określające preferencje muzyczne osób badanych. 


\section{BIBLIOGRAFIA}

Anderson, J. (1983). Retrieval of information from long-term memory. Science, 20(4592): 25-30.

Baldwin, C. i Lewis, B. (2017). Positive valence music restores executive control over sustained attention. Plos One, 12(11): 1-12.

Bray, S., Oliver, J., Graham, J., Ginis, K. (2013). Music, emotion and self-control: does listening to uplifting music replenish self-control strength for exercise? Journal of Applied Biobehavioral Research, 18(3): 156-173.

Bühner, M., König, C., Pick, M., Krumm, S. (2006). Working memory dimensions as differentia predictors of the Speer and terror aspect of multitasking performance. Human Performance, 19(3): 253-275.

Carr, S. i Rickard, N. (2010). The influence of music on memory for images. W: Proceedings of the $11^{\text {th }}$ International Conference on Music Perception and Cognition. Seattle: Causal Productions.

Czerniawska, E. (2012). Czy słuchanie muzyki może wspomóc procesy poznawcze? W: E. Czerniawska, Muzyka i my. O różnych przejawach wpływu muzyki na człowieka (s. 69-88). Warszawa: Difin.

Furnham, A. i Allass, K. (1999). The influence of musical distraction of varying complexity on the cognitive performance of extroverts and introverts. European Journal of Personality, 13(1): 27-38.

Jäncke, L. i Sandmann, P. (2010). Music listening while you learn: no influence of beckground music on verbal learning. Behavioral and Brain Functions, 6(3): 1-15.

Jurek, A. (2012). Skoncentruj się. Zestaw ćwiczeń dla uczniów gimnazjum i szkót ponadgimnazjalnych. Gdańsk: Harmonia.

Lummis, S., McCabe, J., Sickles, A., Byler, R., Hochberg, S., Eckart, S., Kahler, C. (2017). Lyrical memory: Mnemonic effect of music for musicians and nonmusicians. Journal of Psychological Research, 22(2): 141-150.

Manturzewska, M. (1999). Wybrane zagadnienia z psychologii muzyki. Warszawa: Wydawnictwa Szkolne i Pedagogiczne.

Pałosz, P. (2009). Przegląd badań nad uwarunkowaniami preferencji muzycznych. Przegląd Psychologiczny, 52(2): 151-179.

Perham, N. i Currie, H. (2014). Does listening to prefferred music improve reading comprehension performance. Cognitive Psychology, 28: 279-284.

Ralph, B.C.W., Thomson, D.R., Cheyne, J.A., Smilek, D. (2014). Media multitasking and failures of attention in everyday life. Psychological Research, 78: 661-669.

Sloboda, J.A. (2002). Umyst muzyczny. Poznawcza psychologia muzyki. Warszawa: Akademia Muzyczna im. Fryderyka Chopina. Katedra Psychologii Muzyki.

Wasiela, A. (2004). Wpływ muzyki uspokajającej i pobudzającej na wyniki w teście koncentracji uwagi u ekstrawertyków i introwertyków. Nowiny Psychologiczne, 2: 77-90.

Wierszyłowski, J. (1981). Psychologia muzyki. Warszawa: PWN.

Zwolińska, E. (2014). Sposoby audiacji. O myśleniu muzycznym. Bydgoszcz: Wydawnictwo Uniwersytetu Kazimierza Wielkiego. 